Article

\title{
Impact of Land Use Rights Transfer on Household Labor Productivity: A Study Applying Propensity Score Matching in Chongqing, China
}

\author{
Yahui Wang ${ }^{1,2}$, Liangjie Xin ${ }^{1, *},{\text { Xiubin } \mathrm{Li}^{1} \text { and Jianzhong Yan }}^{3}$ \\ 1 Key Laboratory of Land Surface Pattern and Simulation, Institute of Geographic Sciences and Natural \\ Resources Research, Chinese Academy of Sciences(CAS), Beijing 100101, China; \\ wangyhui.15b@igsnrr.ac.cn (Y.W.); lixb@igsnrr.ac.cn (X.L.) \\ 2 University of Chinese Academy of Sciences, Beijing 100049, China \\ 3 College of Resources and Environment, Southwest University, Chongqing 400716, China; \\ yanjzswu@126.com \\ * Correspondence: xinlj@igsnrr.ac.cn; Tel.: +86-10-6488-9699 \\ Academic Editor: Adrian Muller \\ Received: 5 November 2016; Accepted: 19 December 2016; Published: 22 December 2016
}

\begin{abstract}
In order to improve the rural labor productivity and farmers' income, land use transfer was launched and encouraged in recent years, especially the Thirteenth Five-Year Plan (2016-2020). This study aims to shed light on the impact of land use rights transfer on household labor productivity, based on a case study of Chongqing in China. Studies have revealed that land use transfer entails a process of self-selection and does not occur in a random manner. The study, therefore, addressed the issue of sample selection by applying propensity score matching. The study results suggested significant differences in the effects of land use transfer on household labor productivity. Specifically, renting land from other households had a positive effect on total labor productivity (TLP) and agricultural labor productivity (ALP). Moreover, TLP and ALP were found to be higher for households that rented more land or that were located in plain areas. Renting out land had a robust and positive effect on the TLP and non-agricultural labor productivity (NALP). TLP and NALP were also higher for households that rented out more land or that were located in plain areas. These findings suggest that land use transfer should be actively encouraged in plain areas. However, in mountainous areas, there is a need to pay more attention to expanding agriculture to benefit poor and marginalized populations in these areas.
\end{abstract}

Keywords: land use rights transfer; labor productivity; self-selection bias; propensity score matching

\section{Introduction}

The investigation of income generation among farmers is central to the advancement of economic development theory. Moreover, enhancing incomes is critical for improving household labor productivity in rural areas [1]. Following the initiation of China's reform and opening up process, expanding industrialization has been accompanied by a rapid increase in non-agricultural labor productivity (NALP), which is indicative of the level of industrial development. Because of the slow pace of agricultural development over time, there is currently significant disparity between the incomes of urban and rural residents. The low level of labor productivity of rural households has significantly impeded the growth of agriculture and farmers' income [2,3]. To improve rural labor productivity, the Chinese government has recently launched and promoted a system of land use rights transfer. This is evident in the thirteenth Five-Year Plan (2016-2020), which includes, among its aims, orderly promotion of land use rights transfer according to law and the promotion of various forms of agricultural management at moderate scales. 
Studies that have examined problems in rural China have shown that the proportion of land use rights transfer reached approximately $30 \%$ by 2015 [4,5]. This figure is very likely to increase over the next few years, given further support extended by the Chinese government. The key question addressed in this study, which uses household-level data obtained from five counties in the city of Chongqing, is whether land use rights transfer contributes to an increase in labor productivity.

The existing literature reveals an abundance of empirical studies on the effects of land use transfer. These show that expanding the area of farmland is an effective way of improving rural labor productivity [6-8], especially in the current context of China's agricultural development. Furthermore, studies have indicated that land use transfer is the best option for expanding the scale of farming [9]. The topic of land use rights transfer has increasingly attracted the attention of scholars, who have mostly focused on the impacts of land use transfer on land productivity or farmers' incomes [10]. Data obtained from underdeveloped areas in China suggest that land transfer can increase farmers' incomes by raising non-agricultural incomes [11,12]. Data acquired on households that operate micro farms across 17 provinces showed that land transfer could improve farmers' incomes by improving the efficiency of resource allocation [2]. The impacts of land transfer on labor productivity have also been steadily gaining the attention of researchers in recent years. Applying the data envelopment analysis (DEA) method, Yao and Liu found that land use transfer could significantly improve rural labor productivity [13]. Similarly, studies using multivariate regression analysis have revealed that land use transfer improves rural labor productivity $[12,14]$.

It is notable that a key weakness shared by many of the abovementioned studies is that they do not explicitly identify a causal effect of land use rights transfer on labor productivity Theoretical inference and empirical analysis suggest that farm households with higher agricultural labor productivity are more inclined to rent land, and conversely, those with higher non-agricultural labor productivity are more inclined to rent out land $[15,16]$. Consequently, observable improvements in labor productivity may be driven by other factors, rather than by land use rights transfer itself. To accurately assess the impacts of land use rights transfer on labor productivity, researchers need to assess the situation of farm households that have not engaged in land use rights transfer. Without this assessment, any conclusions that are reached can be misleading. However, there is a paucity of literature that addresses this problem, resulting in little evidence in this regard.

Moreover, while most studies in this field have demonstrated that land use transfer can significantly improve labor productivity, the direction of land transfer (renting land from others or renting out land), as well as regional heterogeneity have not been considered. Moreover, the issue of small sample bias must be attended to.

In this study, the abovementioned issues and that of self-selection bias were addressed by applying propensity score matching (PSM). Additionally, the bootstrap method was used to control for small sample bias. The following research questions were investigated. First, does the land use transfer significantly improve household labor productivity? Second, are the effects of land transfer on labor productivity significantly differentiated according to the scale at which land use rights transfer is implemented? Third, do the impacts of land transfer on labor productivity vary significantly across geographical regions? Answers to these questions are urgently required as inputs into the procedure of land use transfer in China.

The remainder of the paper is organized as follows: Section 2 outlines the theoretical analysis and empirical method applied for the study. Section 3 presents data on the situation of land transfer and some descriptive statistics relating to the main variables used in the analysis. Section 4 discusses the results of the analysis using the PSM method to assess the effects of renting land on labor productivity. The following section presents the results of the analysis using the PSM method to assess the effects of renting out land on labor productivity. The final section offers conclusions. 


\section{Research Methodology}

\subsection{Theoretical Analysis}

Theoretical, as well as empirical studies have widely demonstrated that land use transfer could improve household labor productivity. However, we are unable to identify the causal relationship between land use transfer and household labor productivity in most of studies or with traditional multiple regression. In particular, while farm households with higher ALP are more willing to rent land from others, farm households with higher NALP are more inclined to rent out land $[15,16]$.

Starting from the 1980s, the issue of non-randomization, for example, self-selection, has been gradually gaining scholarly attention. Within experiments conducted in the field of economics, policy-influenced samples have been considered as treatment groups, while samples that have not been influenced by policy have been considered as control groups [17]. In this study, the two sets of samples were the treatment and control groups. Here, the treatment group comprised farm households that had already engaged in land use rights transfer (including renting land from others and renting out land). The control group comprised farm households that had not been involved in land use rights transfer. The PSM method was applied because of its effectiveness in solving the issue of non-randomization by identifying an appropriate comparable matching object from the control group, according to the propensity score (p-score), in relation to an object from the treatment group. Consequently, both self-selection and confounding bias were eliminated.

\subsection{The Propensity Score Matching Procedure}

In this study, it was assumed that land use rights transfer was a function of a series of observable characteristics associated with farm households. Thus, the study examined whether the households involved in land use rights transfer were influenced by other factors, such as labor characteristics and family and land assets. The observable characteristics of farm households balanced distributions of observed characteristics between a treatment group and a control group based on the similarity of their predicted probabilities of engaging in the transfer of land use rights.

The main feature of the matching procedure entailed creating the conditions of a randomized experiment to assess the impact of land use rights transfer on household labor productivity, as in a controlled experiment. This required an assumption of conditional independence, indicating that after controlling for $\mathrm{X}$, which represented a series of observable characteristics related to farm households, land use transfer was considered a random behavior that was uncorrelated with labor productivity.

Thus, the effect function of land use rights transfer was expressed as:

$$
\varphi(\mathrm{X})=\mathrm{E}\left[\mathrm{Y}_{\mathrm{i}}^{1}-\mathrm{Y}_{\mathrm{i}}^{0} \mid \mathrm{X}\right]=\mathrm{E}\left[\mathrm{Y}_{\mathrm{i}}^{1} \mid \mathrm{T}=1, \mathrm{X}\right]-\mathrm{E}\left[\mathrm{Y}_{\mathrm{i}}^{0} \mid \mathrm{T}=0, \mathrm{X}\right]
$$

where the average effect of land use transfer was:

$$
\mathrm{ATT}=\mathrm{E}\{\varphi(\mathrm{X})\}
$$

where $Y_{\mathrm{i}}^{1}$ and $\mathrm{Y}_{\mathrm{i}}^{0}$ denote labor productivity in farm household $\mathrm{i}$ in case the household is involved in land use transfer and is not involved, respectively. $\mathrm{T}=1$ indicates households involved in land use rights transfer, whereas $\mathrm{T}=0$ indicates households not involved in land use rights transfer. $X$ includes observed variables influencing the choice of whether to implement land use rights transfer. ATT represents the average effect of labor productivity resulting from land use rights transfer. 
As revealed by the above analysis, as long as land use rights transfer occurs randomly, the labor productivity of similar farm households with different statuses of land use rights transfer (i.e., those involved in land use rights transfer and those not involved in land use transfer) can be compared, defining these households according to the values of other X variables. The PSM method can reduce the high level of dimensionality of the households, and specifically the conditioning problem, by comparing farm households with the same probability land use transfer based on the relevant controls relating to $X[17-19]$.

At this point, a definition of the conditional probability of the involvement of farming household $i$ in land use rights transfer is required. Based on a series of controls relating to $X$, the conditional probability equation can be expressed as follows:

$$
\mathrm{p}\left(\mathrm{X}_{\mathrm{i}}\right)=\operatorname{pr}\left(\mathrm{T}_{\mathrm{i}}=1 \mid \mathrm{X}_{\mathrm{i}}\right)=\frac{\exp \left(\beta \mathrm{X}_{\mathrm{i}}\right)}{1+\exp \left(\beta \mathrm{X}_{\mathrm{i}}\right)}
$$

where $\mathrm{p}\left(\mathrm{X}_{\mathrm{i}}\right)$ is the propensity score (p-score) representing the conditional probability of involvement in land use rights transfer, $\mathrm{Xi}$ indicates observable characteristics related to farm household $\mathrm{i}$. Based on p-scores, similar farm households within the treatment and control groups, respectively, can be found.

It should be noted that the p-score estimation ranks farm households according to their own behavior relating to land use rights transfer. In other words, the study assessed the impact of land use rights transfer among groups of farm households evidencing similar kinds of behavior. This was a crucial aspect of the study, because it is necessary to consider a farm household's choice of whether or not to engage in land use rights transfer when assessing the causal effect of land transfer on its labor productivity.

Up to now, it has not been possible to estimate the impact of land use rights transfer on labor productivity, despite estimating p-scores and matching samples. The main reason for this is that the $\mathrm{p}$-score is a continuous variable, and it is difficult to find two farm households that have identical p-scores within different groups. Consequently, p-scores should be used to match each farm household in the treatment group with a household from the control group. There are several suggestions of appropriate matching methods in the literature for solving this problem. Three of the most widely-used methods are: nearest neighbor matching (NNM), radius-based matching (RBM) and kernel-based matching (KBM) [20].

The NNM method entails backward and forward searching to identify one or several of the closest $\mathrm{p}$-scores for the treatment group from the samples in the control group. Consequently, two samples within different groups with similar p-scores are matched. The second method, RBM, entails searching for all samples in the control group occurring within a radius $\mathrm{R}$ and matching these samples with those in the treatment group. The third method, KBM, is somewhat different from the previous two methods. It entails the construction of a fictitious farm household for matching each farm household within the treatment group. In other words, each farm household within the treatment group is matched with a weighted average of all of the weighted controls that are inversely proportional to the distance between the p-scores of the treatment and control samples.

After conducting the sample matching, it was necessary to test whether the two farm households from different groups were in fact similar. The test was performed using two diagnostic indexes, namely the balancing hypothesis and common support assumption. According to the balancing hypothesis, farm households with the same p-scores should demonstrate the same distribution of $X$, regardless of their land use rights transfer status. This test was crucial for checking whether the behavior of farm households within each group was actually similar. The second test, which was based on an assumption of common support, required the p-score density function of the two groups to be proximate, indicating similar characteristics of $X$ in both groups after matching. Simultaneous satisfaction of the balancing hypothesis and the common support assumption would demonstrate that the farm households did in fact behave similarly [21]. 
As the final step, the impact of land use rights transfer on household labor productivity was estimated. However, the issue of small sample bias in the statistical analysis remained, requiring attention. To reduce small sample bias, the bootstrap method was used to estimate standard errors for further analysis [22]. The impact of land use rights transfer on labor productivity (ATT) was consequently expressed as:

$$
\mathrm{ATT}=\mathrm{E}\left[\mathrm{Y}_{\mathrm{i}}^{1}-\mathrm{Y}_{\mathrm{i}}^{0} \mid \mathrm{T}_{\mathrm{i}}=1\right]=\mathrm{E}\left\{\mathrm{E}\left[\mathrm{Y}_{\mathrm{i}}^{1} \mid \mathrm{T}_{\mathrm{i}}=1, \mathrm{p}\left(\mathrm{X}_{\mathrm{i}}\right)\right]-\mathrm{E}\left[\mathrm{Y}_{\mathrm{i}}^{0} \mid \mathrm{T}_{\mathrm{i}}=0, \mathrm{p}\left(\mathrm{X}_{\mathrm{i}}\right)\right]\right\}
$$

where $T_{i}$ denotes the status of a farm household $i, T_{i}=1$ denotes a farm household engaged in land use rights transfer and $T_{i}=0$ conversely denotes a farm household not engaged in land use rights transfer. The other parameters remained the same as above.

\section{Data and Descriptive Statistics}

\subsection{Data and Samples}

The data for this study were derived from a survey of farm households conducted by the Chinese Academy of Sciences in the city of Chongqing. The survey focused on the impact of urbanization on ecological pressure in southwestern China. The samples are composed of two parts, which includes samples in 2012 and samples in 2014. The first part of the samples extended across three counties (Wulong, Youyang and Wushan) in a mountainous area, and the second part of the samples was surveyed in two counties in a plain, Yougchuan and Zhongxian. To ensure unbiased and representative sampling, there are four stages in the sampling process, i.e., the county, township, village and household. Specifically, probability proportional to size (PPS) sampling was adopted according to the population size in the county. In the county sampling stage, the PPS method was used based on the population size of the county in 2011, using the regional population and gross domestic product (GDP) as a stratified index and randomly extracting five counties. At the township-level sampling stage, according to the PPS method, we randomly selected two or three townships in every county. A similar method was applied to the village- and household-level sampling stages. About 40-50 households were surveyed in each village, and two or three villages were investigated in each township. Finally, 1659 samples were obtained.

These samples were chosen to provide representative examples of agricultural and industrial contexts in mountainous and plain areas. In addition, the phenomena of abandoned farmland and land use rights transfer coexist in this region, which is representative of most regions in China. This study will help to advance understanding of the actual impacts of land use rights transfer in Chongqing and similar areas. The study area and sample distribution are shown in Figure 1.

The following groups of households were filtered out to avoid possible inaccuracies in the data. First, farm households without land were excluded, as their inclusion could have resulted in the underestimation of the actual effects of land use rights transfer. Second, farm households with an effective workforce that exceeded the total number of family members were excluded. Third, to avoid confounding errors, households that simultaneously rented land from others and rented out land were excluded. The final sample comprised 1362 farm households, of which 1102 were located in the mountainous area and 260 in plain areas. 


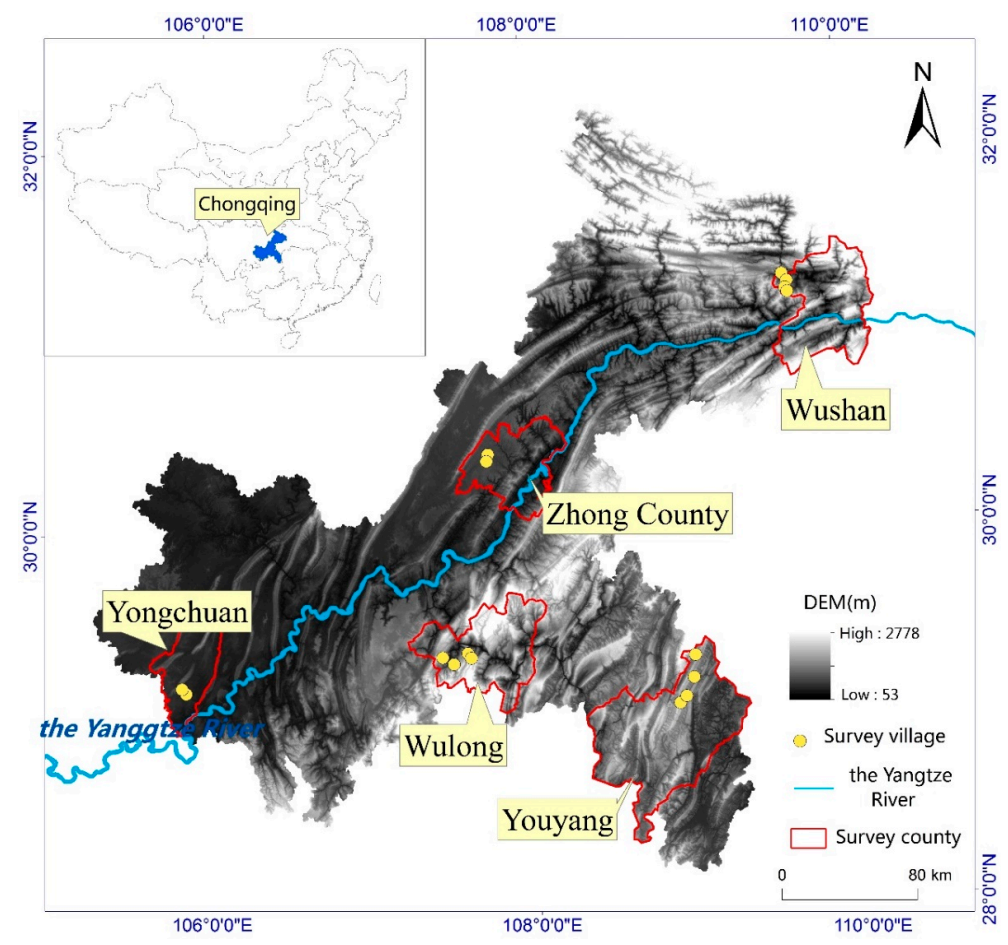

Figure 1. Study area and sample distribution.

\subsection{Descriptive Statistics}

Table 1 shows the status of land use rights transfer among farm households in the surveyed counties.

Table 1. Summary statistics on the status of land transfer in the surveyed counties.

\begin{tabular}{cccccc}
\hline County & $\begin{array}{c}\text { The Number of the } \\
\text { Households with } \\
\text { Renting Land }\end{array}$ & $\begin{array}{c}\text { Proportion } \\
\text { Renting Land } \\
\mathbf{( \% )}\end{array}$ & $\begin{array}{c}\text { The Number of the } \\
\text { Households with } \\
\text { Renting out Land }\end{array}$ & $\begin{array}{c}\text { Proportion } \\
\text { Renting out } \\
\text { Land (\%) }\end{array}$ & Total Number \\
\hline Wulong & 72 & 23.15 & 132 & 42.44 & 311 \\
Youyang & 84 & 19.95 & 226 & 53.68 & 421 \\
Wushan & 74 & 20.00 & 61 & 16.49 & 370 \\
Yongchuan & 24 & 19.35 & 27 & 21.77 & 124 \\
Zhongxian & 42 & 30.88 & 43 & 31.62 & 136 \\
Total & 296 & 22.66 & 489 & 33.2 & 1362 \\
\hline
\end{tabular}

Table 1 shows that $22.66 \%$ of farm households rented land, and $33.2 \%$ of farm households rented out land. In addition, the status of land use rights transfer showed statistical differences according to geographical regions, with the proportion of those renting out land in mountainous areas exceeding that in plain areas by $20 \%-30 \%$. For example, the proportion of those renting out land was $53.68 \%$ in Youyang.

Table 2 presents descriptive statistics on household labor productivity for different categories of land transfer status. Household labor productivity refers to TLP, ALP and NALP, each of which measures a different aspect of labor that reflects a different occupational situation. These are noted below in Table 2. 
Table 2. Descriptive statistics for household labor productivity.

\begin{tabular}{ccccccc}
\hline Groups & Variables & Mean & S.D & Min. & Max. & N \\
\hline \multirow{3}{*}{ Non-rent } & $\log$ (TLP) & 8.81 & 0.94 & 6.48 & 10.66 & 1066 \\
& $\log$ (ALP) & 6.31 & 1.52 & 2.99 & 9.27 & 1066 \\
& $\log$ (NALP) & 8.06 & 2.05 & 2.82 & 10.65 & 1066 \\
\hline \multirow{3}{*}{ Rent } & $\log$ (TLP) & 8.98 & 0.76 & 6.48 & 10.66 & 296 \\
& $\log$ (ALP) & 7.09 & 1.18 & 2.99 & 9.27 & 296 \\
& $\log$ (NALP) & 7.52 & 2.20 & 2.53 & 10.34 & 296 \\
\hline \multirow{3}{*}{ Non-rent out } & $\log$ (TLP) & 8.67 & 0.89 & 6.48 & 10.66 & 873 \\
& $\log$ (ALP) & 6.81 & 1.36 & 2.99 & 9.27 & 873 \\
& $\log$ (NALP) & 7.39 & 2.29 & 2.53 & 10.65 & 873 \\
\hline \multirow{3}{*}{ Rent out } & $\log$ (TLP) & 9.15 & 0.76 & 6.49 & 10.66 & 489 \\
& $\log$ (ALP) & 6.36 & 1.52 & 2.99 & 9.27 & 489 \\
& $\log$ (NALP) & 8.47 & 1.71 & 2.82 & 10.65 & 489 \\
\hline \multirow{2}{*}{ Total Sample } & $\log$ (TLP) & 8.87 & 0.87 & 6.48 & 10.66 & 1362 \\
& $\log$ (ALP) & 6.616 & 1.446 & 2.996 & 9.273 & 1362 \\
& $\log$ (NALP) & 7.851 & 2.127 & 2.526 & 10.65 & 1362 \\
\hline
\end{tabular}

Notes: Because farm households may be engaged in agricultural and non-agricultural activities, agricultural production, such as the output of grain and cash crops, cannot fully represent a household's outputs. Therefore, total household income was used to measure the family output. Specifically, total labor productivity (TLP) was calculated by dividing the total household income by family labor. Agricultural labor productivity (ALP) was calculated by dividing the agricultural income of the household by family agricultural labor. Non-agricultural labor productivity (NALP) was calculated by dividing the non-agricultural family wage income by family non-agricultural labor. Labor productivities were expressed logarithmically to reduce heteroscedasticity and outliers.

The logarithmic expression of TLP indicated that TLP associated with land transfer was $6.18 \%-22.14 \%$ higher than TLP that was not associated with land transfer. Further, for farm households that differed in terms of their land renting status, the respective TLP and ALP of farm households that rented land were $2.1 \%$ and $14.3 \%$ higher than those of farm households that did not rent land. At the same time, the TLP and NALP of households of different statuses relating to renting out land showed significant differences. A surprising finding was the generally high NALP (on average 171.83\%) associated with renting out land. These findings suggested that there were statistical differences between labor productivity associated with land use rights transfer and non-land use rights transfer, respectively, implying that the household labor productivity that either rented land or rented out land could be higher than that of households that did not engage in land use rights transfer.

The findings suggested that land use rights transfer could have an important role in improving household labor productivity. However, the notion that land use rights transfer is endogenous implies that a causal interpretation cannot be applied for a simple comparison of the practices of the transfer and non-transfer of land. Thus, an empirical analysis using micro survey data was performed to assess the extent to which labor productivity improved as a result of land use rights transfer.

\section{Results and Discussions}

As previously mentioned, it was necessary to control for sample self-selection bias. Consequently, the PSM method, developed by Rosenbaum and Rubin, was applied [23]. The specific procedure adopted was as follows. First, the propensity score (p-score) was obtained using a logit model. Second, three matching approaches were used to search for objects from the control group matching with those in the treatment group. Third, the average effect of treatment on the treated group (ATT) was estimated by comparing the different matching groups. 


\subsection{The Impact of Renting Land on Labor Productivity}

\subsubsection{Propensity Score for Renting Land}

As discussed in the literature, the use of a traditional method for conducting multi-dimensional matching is unfeasible. Therefore, a single index that could reflect the characteristics of farm households and that was also suitable for representing the characteristics of the $\mathrm{N}$-dimensional vector, based on farm households, was sought. Table 3 presents summary statistics of the matching variables.

Table 3. Summary statistics for the matching variables based on samples of households renting land.

\begin{tabular}{ccccccc}
\hline Variables & Mean & p50 & SD & Min. & Max. & N \\
\hline AGE & 55.18 & 56.00 & 12.38 & 19.00 & 88.00 & 873 \\
EDU & 2.15 & 2.00 & 0.71 & 1.00 & 5.00 & 873 \\
MARR & 1.27 & 1.00 & 0.75 & 1.00 & 4.00 & 873 \\
HEAL & 2.28 & 3.00 & 0.89 & 1.00 & 4.00 & 873 \\
OCCUP & 0.62 & 1.00 & 0.49 & 0.00 & 1.00 & 873 \\
LABOR & 2.79 & 3.00 & 1.18 & 0.50 & 7.00 & 873 \\
AIR & 0.17 & 0.05 & 0.24 & 0.00 & 0.90 & 873 \\
INCOMEP & 8.79 & 9.00 & 1.01 & 5.52 & 10.66 & 873 \\
AREAP & 2.46 & 1.49 & 3.55 & 0.08 & 26.68 & 873 \\
NOMACH & 2.49 & 2.00 & 1.81 & 0.00 & 9.00 & 873 \\
HASSET & 6.70 & 6.96 & 1.07 & 3.91 & 9.95 & 873 \\
INSURANCE & 0.39 & 0.00 & 0.49 & 0.00 & 1.00 & 873 \\
LOCATION & 0.80 & 1.00 & 0.40 & 0.00 & 1.00 & 873 \\
\hline
\end{tabular}

Notes: Farm households that rented out land were eliminated from these summary statistics of matching variables in the samples, amounting to a total of 873 observations. There were five major groups of matching variables that could influence renting of land. These were: (1) the family head's characteristics, such as AGE (the age of the family head), EDU (the degree of education on a scale of 1-5 with 5 representing the highest educational level), MARR indicates marital status for the head of farm household (4 categories of marital status, with 1 representing the married state) and HEAL (health status ranked from 1-4, with 1 representing optimal health status); (2) household characteristics comprising OCCUP (a dummy variable with 1 denoting a farm household engaged in multiple occupations; otherwise 0); LABOR (the number of members of the household's effective workforce); AIR (the ratio of agricultural income, defined as the agricultural income divided by the total household income); and INCOMEP indicates non-agricultural income for a household (the natural log of the average income); (3) AREAP denotes farmland area (the average per capita cultivated land area); (4) household assets comprising NOMACH (the natural log of the asset value that reflects the number of agricultural machines belonging to a farm household) and HASSET (the natural log of a household's fixed assets; (5) the last group comprised INSURANCE (a dummy variable (1 indicated that a farm household had rural medical insurance; otherwise 0 ) and a second dummy variable, LOCATION ( 1 denoted a farm household with highway access; otherwise 0 ).

Based on the abovementioned characteristics, a logit model was used to predict the probability of renting land, with the aim of estimating the $\mathrm{p}$-score. The model specification was evidently crucial for ensuring that the matching procedure was valid. Table 4 shows the results of five different logit formulations. However, no simple criteria were available for diagnosing the accuracy of the model specifications. Consequently, two indirect diagnostics that are widely reported in the literature, namely pseudo $R^{2}$, which is extensively used in logit regression, and the area under the receiver operating characteristic (ROC) curve (AUC), were applied. Pseudo $\mathrm{R}^{2}$, which has been reported in the literature to have a good fit with micro data, ranged from $0.149-0.159$ for all models. The AUC indicator, which that is widely used in the ROC, can provide more accurate causal inferences. As suggested in the literature, an AUC with a value that is greater than 0.7 can be considered a good indicator that the model's specifications are appropriate [24]. In this study, the AUC exceeded 0.75 for all five models. Thus, the two tests demonstrated that the model specifications were appropriate for the study. 
Table 4. Estimation of the propensity score for renting land.

\begin{tabular}{|c|c|c|c|c|c|}
\hline Logit Specification & (1) & (2) & (3) & (4) & (5) \\
\hline EDU & $\begin{array}{c}-0.198^{* *} \\
(-2.19)\end{array}$ & $\begin{array}{c}-0.202 \text { ** } \\
(-2.12)\end{array}$ & $\begin{array}{c}-0.192 * * \\
(-2.10)\end{array}$ & $\begin{array}{c}-0.199 * * \\
(-2.18)\end{array}$ & $\begin{array}{c}-0.198 \text { ** } \\
(-2.06)\end{array}$ \\
\hline MARR & $\begin{array}{c}-0.234^{* *} \\
(-2.33)\end{array}$ & $\begin{array}{c}-0.233 \text { ** } \\
(-2.30)\end{array}$ & $\begin{array}{c}-0.232 * * \\
(-2.30)\end{array}$ & $\begin{array}{c}-0.235^{* *} \\
(-2.33)\end{array}$ & $\begin{array}{c}-0.231 * * \\
(-2.28)\end{array}$ \\
\hline OCCUP & $\begin{array}{c}0.565^{* * * *} \\
(3.72)\end{array}$ & $\begin{array}{c}0.562 * * * \\
(3.66)\end{array}$ & $\begin{array}{c}0.565^{* * *} \\
(3.73)\end{array}$ & $\begin{array}{c}0.570 * * * \\
(3.53)\end{array}$ & $\begin{array}{c}0.573 * * * \\
(3.47)\end{array}$ \\
\hline LABOR & $\begin{array}{c}0.106 \text { * } \\
(1.76)\end{array}$ & $\begin{array}{c}0.106 \text { * } \\
(1.76)\end{array}$ & $\begin{array}{c}0.113 \text { * } \\
(1.80)\end{array}$ & $\begin{array}{c}0.106^{*} \\
(1.74)\end{array}$ & $\begin{array}{c}0.113 \text { * } \\
(1.80)\end{array}$ \\
\hline AIR & $\begin{array}{c}2.689 * * * \\
(9.13)\end{array}$ & $\begin{array}{c}2.686^{* * *} \\
(9.11)\end{array}$ & $\begin{array}{c}2.661^{* * *} \\
(8.78)\end{array}$ & $\begin{array}{c}2.692 * * * \\
(9.05)\end{array}$ & $\begin{array}{c}2.661^{* * *} \\
(8.74)\end{array}$ \\
\hline AREAP & $\begin{array}{c}-0.082^{* * *} \\
(-3.74)\end{array}$ & $\begin{array}{c}-0.082^{* * * *} \\
(-3.72)\end{array}$ & $\begin{array}{c}-0.082 * * * \\
(-3.74)\end{array}$ & $\begin{array}{c}-0.082^{* * * *} \\
(-3.70)\end{array}$ & $\begin{array}{c}-0.082 \text { *** } \\
(-3.68)\end{array}$ \\
\hline NOMACH & $\begin{array}{c}0.265^{* * *} \\
(6.40)\end{array}$ & $\begin{array}{c}0.266^{* * *} \\
(6.39)\end{array}$ & $\begin{array}{c}0.266^{* * * *} \\
(6.41)\end{array}$ & $\begin{array}{c}0.265^{* * *} \\
(6.40)\end{array}$ & $\begin{array}{c}0.266^{* * *} \\
(6.41)\end{array}$ \\
\hline HASSET & $\begin{array}{c}0.171 \text { ** } \\
(2.55)\end{array}$ & $\begin{array}{c}0.172^{* *} \\
(2.54)\end{array}$ & $\begin{array}{c}0.169 * * \\
(2.53)\end{array}$ & $\begin{array}{c}0.172^{* *} \\
(2.51)\end{array}$ & $\begin{array}{c}0.174^{* *} \\
(2.51)\end{array}$ \\
\hline INSURANCE & $\begin{array}{c}0.346^{* *} \\
(2.42)\end{array}$ & $\begin{array}{c}0.347^{* *} \\
(2.43)\end{array}$ & $\begin{array}{c}0.355^{* *} \\
(2.45)\end{array}$ & $\begin{array}{c}0.342 * * \\
(2.27)\end{array}$ & $\begin{array}{c}0.349 * * \\
(2.30)\end{array}$ \\
\hline LOCATION & $\begin{array}{c}-0.318^{* *} \\
(-2.04)\end{array}$ & $\begin{array}{c}-0.318^{* *} \\
(-2.04)\end{array}$ & $\begin{array}{c}-0.315^{* *} \\
(-2.02)\end{array}$ & $\begin{array}{c}-0.320 * * \\
(-2.04)\end{array}$ & $\begin{array}{c}-0.318^{* *} \\
(-2.03)\end{array}$ \\
\hline AGE & & $\begin{array}{l}-0.001 \\
(-0.15)\end{array}$ & & & $\begin{array}{l}-0.001 \\
(-0.15)\end{array}$ \\
\hline INCOMEP & & & $\begin{array}{l}-0.028 \\
(-0.39)\end{array}$ & & $\begin{array}{l}-0.033 \\
(-0.43)\end{array}$ \\
\hline HEAL & & & & $\begin{array}{l}-0.008 \\
(-0.08)\end{array}$ & $\begin{array}{l}-0.021 \\
(-0.18)\end{array}$ \\
\hline Region dummies & Yes & Yes & Yes & Yes & Yes \\
\hline Constant & $\begin{array}{c}-2.072^{* * *} \\
(-3.62)\end{array}$ & $\begin{array}{c}-2.030 * * * \\
(-3.20)\end{array}$ & $\begin{array}{c}-1.857^{* *} \\
(-2.33)\end{array}$ & $\begin{array}{c}-2.057^{* * *} \\
(-3.40)\end{array}$ & $\begin{array}{c}-1.738 * \\
(-1.88)\end{array}$ \\
\hline Pseudo $R^{2}$ & 0.149 & 0.149 & 0.149 & 0.149 & 0.159 \\
\hline AUC & 0.749 & 0.749 & 0.749 & 0.749 & 0.779 \\
\hline $\mathrm{N}$ & 873 & 873 & 873 & 873 & 873 \\
\hline
\end{tabular}

Notes: The $t$-statistics are shown in parenthesis. The characteristics of households located within the same village were excluded, and standard errors were clustered at the village level. The dependent variable was a binary variable, with 1 denoting renting land and 0 denoting non-renting of land. * Significant at $10 \%$; ** significant at $5 \%$; ${ }^{* * *}$ significant at $1 \%$.

Model (3), shown in Table 4, was estimated using the maximum likelihood estimate (MLE) based on a backward stepwise method. There are part of the characteristics variables for Models (1)-(4). Model (5) was based on whole variables that could have more influence on household behavior relating to land use rights transfer than other specifications. Therefore, Model (5) was used to calculate the p-score in this study.

The results presented in Table 4 showed that EDU (education) and MARR were significantly negative at the $5 \%$ level, indicating that households with higher education and instable marriage were inclined to rent out land. According to the household characteristics, OCCUP (occupation), AIR (agricultural income ratio), NOMACH (number of machines), LABOR and HASSET (household assets) were significantly positive, which suggested that farm households who engaged in multiple occupations had a more effective workforce and agricultural assets tended to rent in land. In addition, LOCATION was significantly negative at the $5 \%$ level and indicated that farm households with more convenient traffic were more willing to rent out land to engage in non-agricultural employment. All of the evidence supported the view that land was transferred from relatively inefficient households to relatively efficient households. 


\subsubsection{Sample Matching Results}

Estimating p-scores enabled similar samples from different groups to be obtained after the sample matching. The matching procedure produced results that were aligned with both the balancing hypothesis and the common support assumption. Table 5 shows that this finding accords with the balancing hypothesis that significant differences do not exist between variables after matching. In their study, Rosenbaum and Rubin (1985) found that the standard deviations of the matching variables were within a $5 \%$ range and that the $p$-values were not significant after matching, thereby indicating conformity with the balancing hypothesis [25]. Thus, the balancing hypothesis was satisfied in this study.

Table 5. Balancing hypothesis test showing the variables' characteristics before and after matching.

\begin{tabular}{|c|c|c|c|c|c|c|}
\hline \multirow{2}{*}{ Variable } & \multirow{2}{*}{$\begin{array}{c}\text { Unmatched } \\
\text { Matched }\end{array}$} & \multicolumn{2}{|c|}{ Mean } & \multirow{2}{*}{ Bias (\%) } & \multirow{2}{*}{$t$-Value } & \multirow{2}{*}{$p$-Value } \\
\hline & & Treated Group & Control Group & & & \\
\hline \multirow{2}{*}{ EDU } & $\mathrm{U}$ & 2.102 & 2.159 & -8.10 & -1.14 & 0.255 \\
\hline & M & 2.102 & 2.098 & 0.60 & 0.06 & 0.951 \\
\hline \multirow{2}{*}{ MARR } & $\mathrm{U}$ & 1.106 & 1.311 & $-31.2 *$ & -3.91 & 0.000 \\
\hline & M & 1.106 & 1.094 & 1.90 & 0.29 & 0.768 \\
\hline \multirow{2}{*}{ OCCUP } & $\mathrm{U}$ & 0.732 & 0.592 & $29.8 *$ & 4.09 & 0.000 \\
\hline & M & 0.732 & 0.754 & -4.90 & -0.83 & 0.407 \\
\hline \multirow{2}{*}{ LABOR } & $\mathrm{U}$ & 3.012 & 2.746 & $23.6^{*}$ & 3.22 & 0.001 \\
\hline & M & 3.012 & 3.013 & -0.10 & -0.01 & 0.992 \\
\hline \multirow{2}{*}{ AIR } & $\mathrm{U}$ & 0.294 & 0.138 & $58.6 *$ & 9.38 & 0.000 \\
\hline & M & 0.294 & 0.287 & 2.80 & 0.27 & 0.787 \\
\hline \multirow{2}{*}{ AREAP } & $\mathrm{U}$ & 2.301 & 2.489 & -5.50 & -0.75 & 0.453 \\
\hline & M & 2.301 & 2.218 & 3.06 & 1.58 & 0.115 \\
\hline \multirow{2}{*}{ NOMACH } & $\mathrm{U}$ & 3.435 & 2.279 & $61.3 *$ & 9.34 & 0.000 \\
\hline & M & 3.435 & 3.331 & 5.00 & 0.72 & 0.472 \\
\hline \multirow{2}{*}{ HASSET } & $\mathrm{U}$ & 6.95 & 6.641 & $31.5 *$ & 4.15 & 0.000 \\
\hline & M & 6.95 & 6.959 & -1.00 & -0.11 & 0.911 \\
\hline \multirow{2}{*}{ INSURANCE } & $\mathrm{U}$ & 0.309 & 0.409 & $-20.9 *$ & -2.91 & 0.004 \\
\hline & M & 0.309 & 0.307 & 0.40 & 0.05 & 0.961 \\
\hline \multirow{2}{*}{ LOCATION } & $\mathrm{U}$ & 0.739 & 0.815 & $-18.2 *$ & -2.71 & 0.007 \\
\hline & $\mathrm{M}$ & 0.739 & 0.764 & -5.91 & -0.63 & 0.532 \\
\hline
\end{tabular}

Note: * indicates that the difference between unmatched and matched variables was statistically significant at the $95 \%$ level.

Figure 2a,b shows the pre-matching and post-matching kernel density functions of the two groups. It is apparent from the figures that differences in the density functions of the two groups were highly significant prior to conducting the matching procedure. After matching was conducted, the distribution density functions of the two samples were very similar, and there was an evident decrease in their deviations. This evident contrast indicates that the common support assumption was satisfied in this study. 


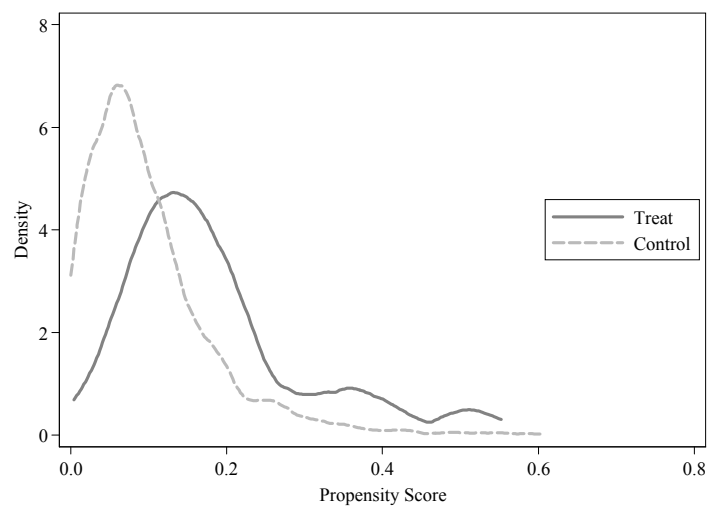

(a)

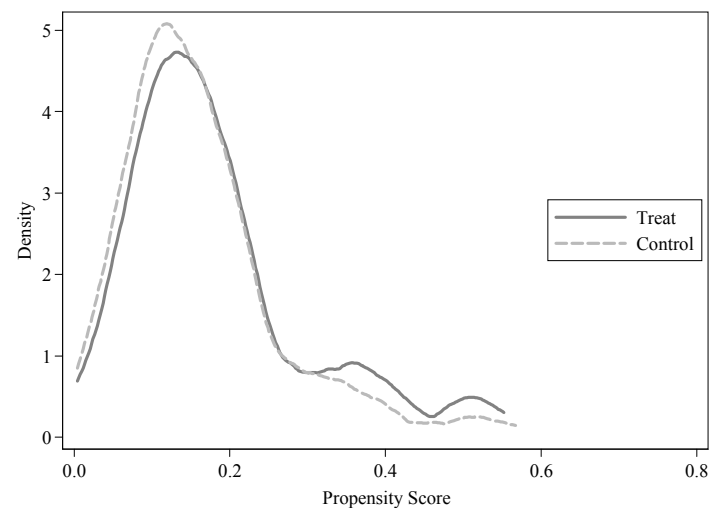

(b)

Figure 2. Common support assumption test to assess the densities of p-scores before and after matching.

(a) Before matching; (b) after matching.

\subsubsection{The Impact of Renting Land on Labor Productivity}

Table 6 shows the average effect of treatment on the treated (ATT) group based on NNM. The ATT of land renting on TLP was significant at a value of 0.137 , which is the average difference between the TLPs of similar pairs of farm households that differ in their land renting status. Expressed logarithmically, the average TLP ratio of renting and non-renting of land was 1.147, and the average TLP of farm households that rented land was $14.6 \%$ higher than the average TLP of households that did not rent land. A second finding was that the ATT of ALP was highly significant at a $1 \%$ significance level. This value of 0.301 represented the average difference between the two groups, and this revealed that the average ALP of farm households that rented land was $34.2 \%$ higher than the ALP of those that did not rent land. The ALP for the treatment group was 7.093 , which was $118.6 \%$-times that of the control group (6.311). This indicates that the impact before matching was overestimated as a result of the influences of other factors. Third, there was no significant difference in the NALP for farm households that rented land and those that did not. The results indicate that renting land can significantly improve the TLP and ALP.

Table 6. Matching estimates for the effects of renting land on labor productivity.

\begin{tabular}{cccccc}
\hline Dep. Variable & Sample & Treated Group & Control Group & ATT & $t$-Value \\
\hline \multirow{2}{*}{$\log ($ TLP) } & pre-matching & 8.811 & 8.907 & -0.096 & -1.99 \\
& post-matching & 8.811 & 8.673 & $0.137^{* *}$ & 2.06 \\
\hline \multirow{2}{*}{$\log ($ ALP) } & pre-matching & 7.093 & 6.311 & $0.782^{* * *}$ & 10.09 \\
& post-matching & 7.093 & 6.791 & $0.301^{* *}$ & 2.89 \\
\hline \multirow{2}{*}{$\log (\mathrm{NALP})$} & pre-matching & 7.522 & 8.062 & $-0.541^{* * *}$ & -4.61 \\
& post-matching & 7.522 & 7.418 & 0.104 & 0.64 \\
\hline
\end{tabular}

Note: ${ }^{*}, * *$ and ${ }^{* * *}$ represent coefficients significant at or under $10 \%, 5 \%$ and $1 \%$ respectively.

Application of the NNM method revealed that the ATTs of the TLP and ALP changed differentially in relation to the scale of land use rights transfer. Table 7 shows that the ATT of TLP presents an inverted U shape. When farm households rented at least one plot of land, the ATT of the TLP was 0.137 . Thus, the TLP of households that rented land was $14.7 \%$ times higher than that of households that did not rent land. The average TLP of households that rented at least two plots of land was $22 \%$ higher than the TLP of households that did not rent land. However, for households that rented at least three plots, the average TLP was $8.4 \%$ higher than the TLP of households that did not rent land, indicating a reduction in the difference. Furthermore, the ATTs of ALP increased with an expansion of the scale of renting land. The average ALP of farm households that rented at least one plot of 
land was 34\% higher than the ALP of those that did not rent land. Moreover, average ALP values of households that rented at least two plots and at least three plots of land showed improvements of $35 \%$ and $55 \%$, respectively. Robustness tests using the abovementioned methods showed that the results were consistent. These findings, therefore, provide evidence that the ALP of farm households that rented land increased with an expanded scale of renting land. While the average NALP was found to decrease with the expanded scale of renting land, this trend is not salient for this study.

Table 7. The effect of renting land on labor productivity according to different scales of land transfer.

\begin{tabular}{|c|c|c|c|}
\hline \multirow{2}{*}{ Dep. Variables } & $\begin{array}{l}\text { Rent of at Least One } \\
\text { Plot of Land }\end{array}$ & $\begin{array}{c}\text { Rent of at Least Two } \\
\text { Plots of Land }\end{array}$ & $\begin{array}{c}\text { Rent of at Least Three } \\
\text { Plots of Land }\end{array}$ \\
\hline & ATT & ATT & $\mathrm{ATT}^{\mathrm{a}}$ \\
\hline \multicolumn{4}{|c|}{ NNM } \\
\hline $\log (\mathrm{TLP})$ & $\begin{array}{l}0.137^{* *} \\
(2.06)\end{array}$ & $\begin{array}{l}0.199 * * * \\
(2.78)\end{array}$ & $\begin{array}{c}0.081^{*} \\
(1.65)\end{array}$ \\
\hline $\log (\mathrm{ALP})$ & $\begin{array}{c}0.301 * * \\
(2.89)\end{array}$ & $\begin{array}{c}0.302 * * * \\
(2.89)\end{array}$ & $\begin{array}{c}0.441^{* * *} \\
(3.36)\end{array}$ \\
\hline $\log (\mathrm{NALP})$ & $\begin{array}{l}0.104 \\
(0.64)\end{array}$ & $\begin{array}{l}0.015 \\
(0.08)\end{array}$ & $\begin{array}{l}-0.259 \\
(-1.12)\end{array}$ \\
\hline \multicolumn{4}{|c|}{ RBM } \\
\hline $\log (\mathrm{TLP})$ & $\begin{array}{c}0.117 * * \\
(1.99)\end{array}$ & $\begin{array}{l}0.171^{* * *} \\
(2.96)\end{array}$ & $\begin{array}{c}0.109 * \\
(1.67)\end{array}$ \\
\hline $\log (\mathrm{ALP})$ & $\begin{array}{l}0.229 * * \\
(2.31)\end{array}$ & $\begin{array}{l}0.259 * * * \\
(2.76)\end{array}$ & $\begin{array}{c}0.450 * * * \\
(3.88)\end{array}$ \\
\hline $\log (\mathrm{NALP})$ & $\begin{array}{l}0.077 \\
(0.54)\end{array}$ & $\begin{array}{l}0.074 \\
(0.43)\end{array}$ & $\begin{array}{l}-0.066 \\
(-0.32)\end{array}$ \\
\hline \multicolumn{4}{|c|}{$\mathrm{KBM}$} \\
\hline $\log (\mathrm{TLP})$ & $\begin{array}{c}0.115 * \\
(1.92)\end{array}$ & $\begin{array}{c}0.183^{* * *} \\
(3.34)\end{array}$ & $\begin{array}{c}0.093 * \\
(1.65)\end{array}$ \\
\hline $\log (\mathrm{ALP})$ & $\begin{array}{l}0.265^{* * *} \\
(2.75)\end{array}$ & $\begin{array}{l}0.303 * * * \\
(3.15)\end{array}$ & $\begin{array}{l}0.522 * * * \\
(4.91)\end{array}$ \\
\hline $\log (\mathrm{NALP})$ & $\begin{array}{l}0.071 \\
(0.48)\end{array}$ & $\begin{array}{l}0.057 \\
(0.34)\end{array}$ & $\begin{array}{l}-0.196 \\
(-0.99)\end{array}$ \\
\hline Balancing Hypothesis & Yes & Yes & Yes \\
\hline $\begin{array}{c}\text { Common Support } \\
\text { Observations }\end{array}$ & Yes & Yes & Yes \\
\hline Treatment Group & 296 & 182 & 108 \\
\hline Control Group & 577 & 691 & 765 \\
\hline
\end{tabular}

Notes: $t$-statistics are shown in parenthesis; ATT $^{\text {a }}$ denotes kernel-based matching with bootstraps' $t$-statistics and 200 replications. The statistics indicated that the average areas of the first, second and third plots that were rented were $0.0873 \mathrm{ha}, 0.0820$ ha and $0.0727 \mathrm{ha}$, respectively. ${ }^{*}, * *$, and ${ }^{* * *}$ represent coefficients significant at or under $10 \%, 5 \%$ and $1 \%$ respectively.

Furthermore, as indicated by the comparative results obtained for TLP, ALP and NALP, shown in Columns A and B of Table 8, renting land had differential impacts in mountainous and plain areas. In mountainous areas, the ATTs of labor productivities (including TLP, ALP and NALP) obtained using the NNM method were not significant. There was no evidence that renting land could significantly improve household labor productivity. Conversely, in plain areas, the ATTs of TLP and ALP were above zero at the 5\% significance level. Specifically, the ATT of TLP was 0.147 at a 5\% significance level. Expressed logarithmically, the TLP of farm households that rented land was $15.8 \%$ higher than the TLP of households that did not rent land. Similarly, the ALP of farm households in plain areas that rented land was $61.3 \%$ higher than the ALP of those that did not rent land. However, it should be noted that the ATT of NALP was not significant. 
Table 8. The effect of renting land on labor productivity across different regions. NNM, nearest neighbor matching; RBM, radius-based matching; KBM, kernel-based matching.

\begin{tabular}{|c|c|c|}
\hline \multirow{2}{*}{ Dep. Variable } & A: Mountainous Area & B: Plain Area \\
\hline & ATT & $\mathrm{ATT}^{\mathbf{a}}$ \\
\hline \multicolumn{3}{|c|}{ NNM } \\
\hline $\log (\mathrm{TLP})$ & $\begin{array}{l}0.301 \\
(1.14)\end{array}$ & $\begin{array}{l}0.147^{* *} \\
(2.11)\end{array}$ \\
\hline $\log (\mathrm{ALP})$ & $\begin{array}{l}0.793 \\
(1.56)\end{array}$ & $\begin{array}{c}0.477^{* *} \\
(1.77)\end{array}$ \\
\hline $\log (\mathrm{NALP})$ & $\begin{array}{l}-0.486 \\
(-1.50)\end{array}$ & $\begin{array}{l}0.212 \\
(1.15)\end{array}$ \\
\hline \multicolumn{3}{|c|}{ RBM } \\
\hline $\log (\mathrm{TLP})$ & $\begin{array}{l}0.229 \\
(1.10)\end{array}$ & $\begin{array}{l}0.136^{* *} \\
(2.34)\end{array}$ \\
\hline $\log (\mathrm{ALP})$ & $\begin{array}{l}1.064 \\
(1.54)\end{array}$ & $\begin{array}{l}0.451^{* *} \\
(2.78)\end{array}$ \\
\hline $\log (\mathrm{NALP})$ & $\begin{array}{l}-0.403 \\
(-1.54)\end{array}$ & $\begin{array}{l}-0.621 \\
(-1.53)\end{array}$ \\
\hline \multicolumn{3}{|c|}{$\mathrm{KBM}$} \\
\hline $\log (\mathrm{TLP})$ & $\begin{array}{l}0.351 \\
(1.36)\end{array}$ & $\begin{array}{l}0.136^{* *} \\
(2.13)\end{array}$ \\
\hline $\log (\mathrm{ALP})$ & $\begin{array}{l}1.021 \\
(1.51)\end{array}$ & $\begin{array}{c}0.493^{* *} \\
(2.51)\end{array}$ \\
\hline $\log (\mathrm{NALP})$ & $\begin{array}{l}-0.828 * \\
(-1.91)\end{array}$ & $\begin{array}{l}0.102 \\
(1.01)\end{array}$ \\
\hline Balancing Hypothesis & Yes & Yes \\
\hline $\begin{array}{l}\text { Common Support } \\
\text { Observations }\end{array}$ & Yes & Yes \\
\hline Treatment Group & 230 & 66 \\
\hline Control Group & 473 & 194 \\
\hline
\end{tabular}

Notes: "Mountainous area" and "plain area" refer to farm households located in the mountains and in the plains, respectively. ${ }^{*}{ }^{* *}$ represent coefficients significant at or under $10 \%$ and $5 \%$ respectively.

Overall, renting land was found to significantly improve labor productivity, for example TLP and ALP. The ALP of farm households that rented more land or located in plain areas was higher than the ALP of those that rented less land or located in mountainous areas. While NALP seemingly decreased with the expansion of the scale of renting land, this effect was not significant. Therefore, it can be inferred that TLP generally increases with an increase of ALP.

\subsection{The Impact of Renting out Land on Labor Productivity}

The above-described methods were also applied to households that rented out land, to estimate p-scores and match samples. The balancing hypothesis and common support assumption were satisfied. Given considerations of space, the results of the p-score estimation and the sample matching are not discussed in this section (see Supplementary Materials). Table 9 shows the results relating to the impacts of renting out land on labor productivity. Evidently, highly significant differences existed between pre-matching and post-matching results for the ATTs of TLP, ALP and NALP. For the pre-matching, as well as the post-matching analyses, the ATT of TLP was significant above zero at the $10 \%$ significance level, indicating that renting out land could indeed improve TLP. This finding indicates that the TLP of farm households that rented out land was $18.6 \%$ higher than the TLP of those that did not rent out land. In the case of NALP, an improvement of $35.5 \%$ was observed for farm households that rented out land. However, there was no evidence to indicate that ALP improved as a result of renting out land. 
Table 9. Matching estimates for the effect of renting out land on labor productivity.

\begin{tabular}{cccccc}
\hline Dep. Variable & Sample & Treated Group & Control Group & ATT & $t$-Value \\
\hline \multirow{2}{*}{$\log ($ TLP) } & Pre-matching & 9.144 & 8.669 & $0.475^{* * *}$ & 10.34 \\
& Post-Matching & 9.144 & 9.071 & $0.171^{*}$ & 1.66 \\
\hline \multirow{2}{*}{$\log$ (ALP) } & Pre-matching & 6.361 & 6.803 & $-0.442^{* * *}$ & -5.63 \\
& Post-Matching & 6.361 & 6.449 & -0.088 & -0.71 \\
\hline \multirow{2}{*}{$\log$ (NALP) } & Pre-matching & 8.469 & 7.399 & $1.069^{* * *}$ & 9.46 \\
& Post-Matching & 8.469 & 8.266 & $0.303^{*}$ & 1.77 \\
\hline
\end{tabular}

Note: ${ }^{*}$, and ${ }^{* * *}$ represent coefficients significant at or under $10 \%$ and $1 \%$ respectively.

Table 10 shows that there were significant differences in the impacts of renting out land on labor productivity according to the scale of land transfer, as revealed by the application of the NNM procedure. Specifically, with the expansion of the scale of renting out land, the ATTs of TLP and NALP increased. An examination of the relationship between TLP and NALP further revealed that TLP gradually increased with the expansion of NALP associated with renting out land. However, for farm households that rented out at least two plots of land, the ATTs of ALP did not show significant differences. By contrast, the ATT of ALP was below zero at a 5\% significance level for farm households that rented out at least three plots of land. The ALP of these households was $60 \%$ less than that of farm households that did not rent out land. Robustness tests using the RBM and KBM procedures were applied to reexamine the ATTs of labor productivity. These results were consistent with those obtained using the NNM procedure.

Table 10. Impact of renting out land on labor productivity by amounts of land transferred.

\begin{tabular}{|c|c|c|c|}
\hline \multirow{2}{*}{ Variables } & $\begin{array}{l}\text { Renting out at Least } \\
\text { One Plot of Land }\end{array}$ & $\begin{array}{l}\text { Renting out at Least } \\
\text { Two Plots of Land }\end{array}$ & $\begin{array}{l}\text { Renting out at Least } \\
\text { Three Plots of Land }\end{array}$ \\
\hline & ATT & ATT & $\mathrm{ATT}^{\mathbf{a}}$ \\
\hline \multicolumn{4}{|c|}{ NNM } \\
\hline $\log (\mathrm{TLP})$ & $\begin{array}{c}0.171 * \\
(1.66)\end{array}$ & $\begin{array}{l}0.103 \\
(1.56)\end{array}$ & $\begin{array}{c}0.179 * \\
(1.94)\end{array}$ \\
\hline $\log (\mathrm{ALP})$ & $\begin{array}{l}-0.088 \\
(-0.71)\end{array}$ & $\begin{array}{l}-0.058 \\
(-0.43)\end{array}$ & $\begin{array}{c}-0.474^{* *} \\
(-2.79)\end{array}$ \\
\hline $\log (\mathrm{NALP})$ & $\begin{array}{l}0.303 * \\
(1.77)\end{array}$ & $\begin{array}{c}0.422 * * * \\
(3.11)\end{array}$ & $\begin{array}{c}0.773^{* * * *} \\
(4.43)\end{array}$ \\
\hline \multicolumn{4}{|c|}{ RBM } \\
\hline $\log (\mathrm{TLP})$ & $\begin{array}{l}0.107^{*} \\
(1.70)\end{array}$ & $\begin{array}{l}0.069 \\
(1.18)\end{array}$ & $\begin{array}{l}0.171^{* *} \\
(2.23)\end{array}$ \\
\hline $\log (\mathrm{ALP})$ & $\begin{array}{l}-0.145 \\
(-1.39)\end{array}$ & $\begin{array}{l}-0.023 \\
(-0.21)\end{array}$ & $\begin{array}{l}-0.326^{* *} \\
(-2.29)\end{array}$ \\
\hline $\log (\mathrm{NALP})$ & $\begin{array}{l}0.318^{* *} \\
(2.03)\end{array}$ & $\begin{array}{c}0.416^{* * * *} \\
(3.92)\end{array}$ & $\begin{array}{c}0.796^{* * *} \\
(5.26)\end{array}$ \\
\hline \multicolumn{4}{|c|}{ KBM } \\
\hline $\log (\mathrm{TLP})$ & $\begin{array}{l}0.109 * \\
(1.72)\end{array}$ & $\begin{array}{l}0.070 \\
(1.19)\end{array}$ & $\begin{array}{c}0.171^{* *} \\
(2.24)\end{array}$ \\
\hline $\log (\mathrm{ALP})$ & $\begin{array}{l}-0.148 \\
(-1.42)\end{array}$ & $\begin{array}{l}-0.031 \\
(-0.23)\end{array}$ & $\begin{array}{l}-0.337 \\
(-2.36)\end{array}$ \\
\hline $\log (\mathrm{NALP})$ & $\begin{array}{l}0.324^{* *} \\
(2.07)\end{array}$ & $\begin{array}{l}0.416^{* * *} \\
(3.91)\end{array}$ & $\begin{array}{c}0.809^{* * * *} \\
(5.31)\end{array}$ \\
\hline Balancing Hypothesis & Yes & Yes & Yes \\
\hline $\begin{array}{l}\text { Common Support } \\
\text { Observations }\end{array}$ & Yes & Yes & Yes \\
\hline Treatment Group & 426 & 165 & 145 \\
\hline Control Group & 640 & 901 & 921 \\
\hline
\end{tabular}

Notes: $t$-statistics are provided in parenthesis. ${ }^{*}, * *$, and ${ }^{* * *}$ represent coefficients significant at or under $10 \%, 5 \%$ and $1 \%$ respectively. The average areas of the rented out plots were $0.0923 \mathrm{ha}, 0.0887$ ha and 0.0747 ha, respectively. 
Farm households were further categorized into two subgroups based on their geographic locations in mountainous and plain areas. The results are shown in Columns $C$ and D in Table 11, revealing that the ATTs of different labor productivities in the mountainous area were not significant. Thus, no evidence was found that renting out land could improve labor productivities for farm households located in the mountainous area. However, the results using all three matching methods, presented in Column D, show that the ATTs of TLP and NALP were above zero at the $1 \%$ significance level. Therefore, renting out land was found to significantly improve the TLP and NALP for farm households located in the plain areas. Specifically, the ATT of TLP shown in Column D was 0.409, indicating that the average TLP ratio of renting out land and not renting out land was 1.505, and the results demonstrate that in the plain areas, the TLP of farm households that rented out land was $50.5 \%$ higher than the TLP of households that did not rent out land. Further, the results showed that the NALP for households that rented out land was $155.9 \%$ higher than the NALP of households that did not rent out land. However, the ATTs of ALP were not significant. Thus, there was no evidence that renting out land could improve the ALP of households located in plain areas. The results were verified through robustness tests applying the RBM and KBM methods. The results of these tests were consistent for the ATTs of TLP, ALP and NALP.

Table 11. Impact of renting out land on labor productivity across different regions.

\begin{tabular}{|c|c|c|}
\hline \multirow{2}{*}{ Dep. Variable } & C: Mountainous Area & D: Plain Area \\
\hline & ATT & ATT $^{a}$ \\
\hline \multicolumn{3}{|c|}{ NNM } \\
\hline $\log (\mathrm{TLP})$ & $\begin{array}{l}0.521 \\
(1.39)\end{array}$ & $\begin{array}{l}0.409 * * * \\
(5.92)\end{array}$ \\
\hline $\log (\mathrm{ALP})$ & $\begin{array}{l}-0.241 \\
(-0.42)\end{array}$ & $\begin{array}{l}-0.008 \\
(-0.07)\end{array}$ \\
\hline $\log$ (NALP) & $\begin{array}{l}0.475 \\
(0.75)\end{array}$ & $\begin{array}{c}0.942 \text { *** } \\
(5.19)\end{array}$ \\
\hline \multicolumn{3}{|c|}{ RBM } \\
\hline $\log (\mathrm{TLP})$ & $\begin{array}{l}0.466 \\
(1.37)\end{array}$ & $\begin{array}{c}0.345^{* * *} \\
(6.07)\end{array}$ \\
\hline $\log (\mathrm{ALP})$ & $\begin{array}{l}-0.531 \\
(-0.99)\end{array}$ & $\begin{array}{l}0.028 \\
(0.29)\end{array}$ \\
\hline $\log (\mathrm{NALP})$ & $\begin{array}{l}0.428 \\
(0.72)\end{array}$ & $\begin{array}{c}0.781^{* * *} \\
(5.07)\end{array}$ \\
\hline \multicolumn{3}{|c|}{ KBM } \\
\hline $\log (\mathrm{TLP})$ & $\begin{array}{l}0.469 \\
(1.33)\end{array}$ & $\begin{array}{c}0.345^{* * *} \\
(6.04)\end{array}$ \\
\hline $\log (\mathrm{ALP})$ & $\begin{array}{l}-0.581 \\
(-1.05)\end{array}$ & $\begin{array}{l}0.032 \\
(0.34)\end{array}$ \\
\hline $\log (\mathrm{NALP})$ & $\begin{array}{l}0.437 \\
(0.71)\end{array}$ & $\begin{array}{l}0.787^{* * * *} \\
(5.08)\end{array}$ \\
\hline Balancing Hypothesis & Yes & Yes \\
\hline $\begin{array}{l}\text { Common Support } \\
\text { Observations }\end{array}$ & Yes & Yes \\
\hline Treatment Group & 419 & 80 \\
\hline Control Group & 453 & 114 \\
\hline
\end{tabular}

Note: ${ }^{* * *}$ represent coefficients significant at or under $10 \%, 5 \%$ and $1 \%$ respectively.

In summary, the impacts of renting out land could differ based on the scale at which this occurs or the geographic location. Overall, the TLP and NALP were found to be higher in farm households that rented out more land or that were located in plain areas. All conclusions showed that land use transfer can significantly change labor productivity in plains, while there was little work in the 
mountains [26-28]. These results are similar to the conclusions in this study. Obviously, it is important to implement land use transfer for improving labor productivity both in China or other countries.

\section{Conclusions and Policy Implications}

This study shed light on the impact of land use transfer on household labor productivity based on 1362 farm households form Chongqing in China. The application of the PSM revealed that land use transfer had a significant impact on the TLP and ALP of households, and the impact could be affected by the scale of land renting and geographical location. In addition, the ATTs of TLP and ALP were higher for households who rent in more land or that are located in plain areas. On the other hand, renting out land had a positive impact on the TLP and NALP of households. Furthermore, the ATTs of TLP and NALP were found to be higher for households who rented out more land or that were located in plain areas. Overall, there appears to be a strong imperative for improving household labor productivity and increasing household income in rural areas in China. In plain areas, land use transfer should be encouraged, and agricultural management at a moderate scale should be promoted. This activity, entailing renting in, as well as renting out land, can improve household income as a result of increased TLP. However, in mountainous areas, because of geographical and resource constraints, farm households find it very difficult to engage in land use transfer to improve their labor productivity and increase their income. As non-agricultural wages continue to rise, massive labor forces flow from mountain areas to urban [29]. The elderly labor still stays in the mountain areas, and their abilities are limited. They are engaged in self-sufficient agriculture at a small scale due to land fragmentation, complex terrain and poor land quality in mountain areas. It is obvious that subsistence agriculture that can satisfy the basic livelihood still exists in the mountains, especially in Chongqing, and agricultural mechanization and agricultural modernization cannot be achieved at present. Considering the particularity of the mountains, a considerable proportion of the farmland has been abandoned, and only depending on land use transfer is very difficult to increase farmer' income [30]. Therefore, the government should devote more attention to promoting agricultural growth focused on marginalized and poor populations in these areas.

It is noteworthy that land use transfer has been encouraged in Document No. 1 in 1993, the Third Plenary Session of the 15th Communist Party of China in 1998 and Laws and Regulations in 2005 to improve labor productivity. This was evident in the Thirteenth Five-Year Plan (2016-2020), which includes, among its aims, orderly promotion of land use transfer according to law and the promotion of various forms of agricultural management at moderate scales. However, the proportion of land in circulation was chose $30 \%$ in 2015 , but there were still about ten provinces where the figures were less than $10 \%$. Obviously, more than $70 \%$ of farmers did not participate in land use transfer. The proportion of non-participation remained high compared to corresponding estimates of $54 \%$ in India and 37\% in Bangladesh [4,5]. Why is the proportion of land in circulation in China still on the low side? The existing literature suggested that the inefficiency of the land rental market was caused by high transaction costs in other countries [31,32], together with the instability of land rights and land fragmentation. However, the research about what causes the low proportion of land in circulation in China is still inadequate, and this research still needs attention paid to it. Of course, the problems are the focus of attention in the future.

Furthermore, the priority of this study was to evaluate the impact of land use transfer on labor productivity. However, the influence mechanisms of land use transfer on labor productivity should be strengthened for further research, especially the channels to achieve the change of household labor productivity.

Supplementary Materials: The following are available online at www.mdpi.com/2071-1050/9/1/4/s1, Table S1: Summary statistics for the matching variables based on the samples of households renting out land, Table S2: Estimation of the propensity score for renting out land, Table S3: Balancing hypothesis test: variables' characteristics of before and after the match (renting out land), Figure S1: Common support test: renting out land. (a) Before matching; (b) after matching. 
Acknowledgments: This work was funded by the National Natural Science Foundation of China (Grant Numbers 41161140352, 41571095, 41271119).

Author Contributions: Yahui Wang calculated and analyzed the data in addition to writing the paper. Liangjie Xin designed the research project. Xiubin Li gave suggestions for the whole study. Jianzhong Yan helped with the field research and contributed to the data. Many thanks go to the anonymous reviewers for their valuable comments on the manuscript.

Conflicts of Interest: The authors declare no conflict of interest.

\section{Abbreviations}

The following abbreviations are used in this manuscript:

GDP Gross Domestic Product

TLP Total Labor Productivity

ALP Agricultural Labor Productivity

NALP Non-Agricultural Labor Productivity

ATT Average effect of Treatment on the Treated

\section{References}

1. Xie, Y.; Jiang, Q.B. Land arrangements for rural-urban migrant workers in china: Findings from Jiangsu province. Land Use Policy 2016, 50, 262-267. [CrossRef]

2. Christiaensen, L.; Pan, L.; Wang, S.G. Pathways out of poverty in lagging regions: Evidence from rural western China. Agric. Econ. 2013, 44, 25-44. [CrossRef]

3. Jin, S.Q.; Jayne, T.S. Land rental markets in kenya: Implications for efficiency, equity, household income, and poverty. Land Econ. 2013, 89, 246-271. [CrossRef]

4. Deininger, K.; Jin, S.Q.; Nagarajan, H.K. Efficiency and equity impacts of rural land rental restrictions: Evidence from India. Eur. Econ. Rev. 2008, 52, 892-918. [CrossRef]

5. Rahman, S. Determinants of agricultural land rental market transactions in bangladesh. Land Use Policy 2010, 27, 957-964. [CrossRef]

6. Bravoureta, B.E.; Evenson, R.E. Efficiency in agricultural production-The case of peasant farmers in eastern paraguay. Agric. Econ. 1994, 10, 27-37. [CrossRef]

7. Wang, J.Y.; Chen, K.Z.; das Gupta, S.; Huang, Z.H. Is small still beautiful? A comparative study of rice farm size and productivity in China and India. China Agric. Econ. Rev. 2015, 7, 484-509. [CrossRef]

8. Zenka, J.; Slach, O.; Krticka, L.; Zufan, P. Determinants of microregional agricultural labour productivity-Evidence from Czechia. Appl. Geogr. 2016, 71, 83-94. [CrossRef]

9. Benin, S.; Ahmed, M.; Pender, J.; Ehui, S. Development of land rental markets and agricultural productivity growth: The case of northern Ethiopia. J. Afr. Econ. 2005, 14, 21-54. [CrossRef]

10. Pender, J.; Fafchamps, M. Land lease markets and agricultural efficiency in Ethiopia. J. Afr. Econ. 2006, 15, 251-284. [CrossRef]

11. Holden, S.; Yohannes, H. Land redistribution, tenure insecurity, and intensity of production: A study of farm households in southern Ethiopia. Land Econ. 2002, 78, 573-590. [CrossRef]

12. Deininger, K.; Jin, S.Q.; Xia, F. Moving off the farm: Land institutions to facilitate structural transformation and agricultural productivity growth in China. World Dev. 2014, 59, 505-520. [CrossRef]

13. Yao, S.B.; Liu, Z. An Empirical Analysis of Agricultural Productivity in the Sloping Land Conversion Region Based on Dea Mode; Alfred University: Alfred, NY, USA, 2009; pp. 2587-2595.

14. Wang, G.G.; Liu, Y.S.; Li, Y.R.; Chen, Y.F. Dynamic trends and driving forces of land use intensification of cultivated land in China. J. Geogr. Sci. 2015, 25, 45-57. [CrossRef]

15. Carter, M.R.; Yao, Y. Local versus global separability in agricultural household models: The factor price equalization effect of land transfer rights. Am. J. Agric. Econ. 2002, 84, 702-715. [CrossRef]

16. Conning, J.H.; Robinson, J.A. Property rights and the political organization of agriculture. J. Dev. Econ. 2007, 82, 416-447. [CrossRef]

17. Dehejia, R.H.; Wahba, S. Propensity score-matching methods for nonexperimental causal studies. Rev. Econ. Stat. 2002, 84, 151-161. [CrossRef]

18. Heckman, J.J.; Ichimura, H.; Todd, P.E. Matching as an econometric evaluation estimator: Evidence from evaluating a job training programme. Rev. Econ. Stud. 1997, 64, 605-654. [CrossRef] 
19. Haviland, A.; Rosenbaum, P.R.; Nagin, D.S.; Tremblay, R.E. Combining group-based trajectory modeling and propensity score matching for causal inferences in nonexperimental longitudinal data. Dev. Psychol. 2008, 44, 422-436. [CrossRef] [PubMed]

20. Mayne, S.L.; Lee, B.K.; Auchincloss, A.H. Evaluating propensity score methods in a quasi-experimental study of the impact of menu-labeling. PLoS ONE 2015, 10, 12. [CrossRef] [PubMed]

21. Li, A.; Makar, R.S.; Hurwitz, S.; Uhl, L.; Kaufman, R.M.; Stowell, C.P.; Dzik, W.S.; Bendapudi, P.K. Treatment with or without plasma exchange for patients with acquired thrombotic microangiopathy not associated with severe adamts13 deficiency: A propensity score-matched study. Transfusion 2016, 56, 2069-2077. [CrossRef] [PubMed]

22. Li, D.Q.; Tang, X.S.; Zhou, C.B.; Phoon, K.K. Characterization of uncertainty in probabilistic model using bootstrap method and its application to reliability of piles. Appl. Math. Model. 2015, 39, 5310-5326. [CrossRef]

23. Rosenbaum, P.R.; Rubin, D.B. The central role of the propensity score in observational studies for causal effects. Biometrika 1983, 70, 41-55. [CrossRef]

24. Fan, X.L.; Yang, L. Method to assess the accuracy of scores in mortality prediction: More than receiver operating characteristic curve. Eur. J. Gastroenterol. Hepatol. 2016, 28, 850. [CrossRef] [PubMed]

25. Rosenbaum, P.R.; Rubin, D.B. Constructing a control-group using multivariate matched sampling methods that incorporate the propensity score. Am. Stat. 1985, 39, 33-38. [CrossRef]

26. Chen, Y.Y.; An, X.S.; Ling, R.P. The impact of farmland transfer on farmer's production efficiency-A case of northwestern Shanxi. J. Arid Land Resour. Environ. 2015, 29, 45-49.

27. Mao, P.H.; Xu, J.; He, X.D.; Zhou, Y.H. Transfer of Land and Increasse of Farmers' Labor Productivity: Theoretical and Empirical Analysis. Econ. Res. J. 2015, 11, 161-176.

28. Rola, A.C.; Dayo, H.F.; Labios, R.V.; Garcia, A.G. Labor use and labor productivity in the upland rice based farming system: A case of Magallanes, Gavite, Philippines. Rice Farming Syst. Tech. Exch. 1992, 12, 93-108.

29. Yan, J.Z.; Yang, Z.Y.; Li, Z.H.; Li, X.B.; Xing, L.J.; Sun, L.X. Drivers of cropland abandonment in mountainous areas: A household decision model on farming scale in Southwest China. Land Use Policy 2016, 57, 459-469. [CrossRef]

30. Gan, L.; Yin, Z.C.; Tan, J.J. China Household Finance Survey Report 2014; Southwestern University of Finance and Economics Press: Chengdu, China, 2015.

31. Le, V.; Lyne, M.; Ratna, N.; Nuthall, P. The Rental Market for Farmland in Vietnam's Mountainous North Central Coast Region: Outcomes and Constraints. Mt. Res. Dev. 2013, 33, 416-423. [CrossRef]

32. Macours, K. Ethnic divisions, contract choice, and search costs in the Guatemalan land rental market. J. Comp. Econ. 2014, 42, 1-18. [CrossRef]

(C) 2016 by the authors; licensee MDPI, Basel, Switzerland. This article is an open access article distributed under the terms and conditions of the Creative Commons Attribution (CC-BY) license (http://creativecommons.org/licenses/by/4.0/). 